\title{
Influence of Transformational Leadership Style and Motivation of Nurse Satisfaction and Performance
}

\author{
Mirda Faza Lestari ${ }^{1}$, Widaningsih ${ }^{2}$ \\ Magister Management, Economic Business, Esa Unggul University, Jakarta, Indonesia ${ }^{1}$ \\ Magister Management, Economic Business, Esa Unggul University, Jakarta, Indonesia ${ }^{2}$
}

\begin{abstract}
Nurses are assets for hospitals, because the largest human resources in health care in hospitals are occupied by nurses, the proportion of nurses among other human resources employed in health care facilities, of the six health workers the number of nurses is the largest reaching $49 \%$ and nurses in hospital use $58.26 \%$ (Ministry of Health RI, 2016). So that the nurse's performance must be considered, the factors that influence performance are leadership style, motivation and job satisfaction. This study aims to determine the effect of transformational leadership style and motivation on job satisfaction and nurse performance. Samples of 172 respondents, the research method used is a quantitative method and this research analysis technique used is Structural Equation Model (SEM) which is operated through the lisrel program. The results of the study prove that transformational leadership and motivation have a significant positive effect on job satisfaction and performance, but job satisfaction has a negative effect on the performance of nurses in the hospital. It was concluded that the increasing transformational leadership style and motivation will increase job satisfaction and nurse performance, but the rise and fall of nurse performance is not affected by job satisfaction.
\end{abstract}

Keywords: Transformational leadership style, motivation, job satisfaction, nurse performance.

\section{PRELIMINARY}

One way to deal with competition in hospitals at this time must have quality human resources. Human resources in the organization are crucial aspects determining the effectiveness of an organization. Therefore, organizations in hospital health care must be considered because human resources are important determinants of the success or failure of the organizational change process.

The largest human resources in health services in hospitals were occupied by nurses, the proportion of nurses among other human resources employed in health care facilities, of the six health workers the largest number of nurses reached $49 \%$, followed by midwives $27 \%$ and $8 \%$ doctors and nurses who were used at the hospital $58.26 \%$ while at the health center $29.46 \%$ (KEMENKES RI, 2016). Nurses are ready to help patients at any time and work 24 hours a day, in turn and continuously to provide comprehensive and professional nursing care. Quality nurses in hospitals are expected to produce a maximum output in the form of products or services to improve services. These problems should be realized that the success of the hospital is partly caused by the nurse, so that the nurse is seen as a hospital asset, even an investment in the hospital if the nurse is a skilled nurse and has good performance.

A good nurse's performance can be seen from how a nurse is able to show the results of her work in providing health services at the hospital. Research conducted by Soleman (2017) in Manado shows that the nurse's performance is still low at $51.5 \%$, the low performance of nurses will be a problem for the hospital, because performance as a benchmark for hospital success, so it is very important to improve nursing performance in a home sick. Improving nurse performance requires several factors that influence performance achievement. There are so many factors that influence performance achievement including leadership style, motivation and job satisfaction (Gibson, 2012).

Leadership is a process of influencing groups to set and achieve goals (Russell and Richard, 1999). Effective leadership must be responsive to change, as well as analyze the strengths and weaknesses of human resources so as to maximize organizational performance and solve problems appropriately. Leaders in their leadership need to think about and demonstrate the leadership style that will be applied to their employees. The existence of a leadership style that is in accordance with the situation and condition of the organization, the employee will be more enthusiastic in carrying out their duties and obligations and have hopes of fulfilling the needs. The fulfilled needs make employees feel satisfied, employees who are satisfied with their work will tend to have high performance.

Leadership style is a combination of different relationship behaviors and behaviors that are used to influence others to achieve goals (Huber, 2017). The boss's leadership style can affect the satisfaction and performance of his followers, this can be seen from the results of research by Abdelhafiz et al. (2015) shows that there is a positive relationship 


\section{International Advanced Research Journal in Science, Engineering and Technology}

Vol. 7, Issue 12, December 2020

\section{DOI 10.17148/IARJSET.2020.71214}

between job satisfaction and the total score of transformational leadership style and research by Khan et al. (2016) shows that the nature of transformational leadership has a positive effect on performance.

Likewise with motivation, a nurse must have motivation that leads to satisfaction and performance, to achieve a level of satisfaction and good performance, each nurse must have high motivation. Motivation is everything that encourages someone to do something (Nursalam, 2014). Research conducted by Soleman (2017) in Manado shows that the nurses' motivation is still low at $54.5 \%$, the low motivation of nurses will be a problem for hospitals, because low motivation will affect the satisfaction and performance of nurses. Research conducted by Ferawati (2016) shows that motivation affects the job satisfaction of nurses, and research by Hee et al. (2016) shows that intrinsic and extrinsic motivation is positively related to nurse performance.

Nurse job satisfaction is needed for nurses to improve health services. Job satisfaction is an affective or emotional response to various aspects of one's work (Kreitner and Kinicki, 2008). If the nurse has positive emotions in a job, then the work gets better. Nurses who are dissatisfied at work have negative feelings causing many problems in the hospital. From the information above, performance needs to be considered because performance is a benchmark for organizational success. Therefore the authors are interested in examining the influence of transformational leadership styles and motivation on job satisfaction and nurse performance.

\section{LITERATURE STUDY}

\section{Transformational Leadership}

There are so many models of leadership style but what will be discussed in this study is transformational leadership style. Some notions of transformational leadership according to experts, transformational leadership is leadership that inspires followers to adopt the values and goals of leaders and set aside their own interests for the good of the organization (Robbins and Judge, 2015). The definition of transformational leadership style in nursing is the nursing leader who motivates his followers (nurses) to work towards goals for the good of the organization. Whereas Ivancevich et al. (2007) states that transformational leadership is a leader who motivates his followers to work towards a goal, not for short-term personal interests, and to achieve self-actualization and achievement, not for the sake of feeling safe. Cherie and Gebrekidan (2013) define transformational leadership as someone who makes people do activities, transform followers into leaders and turn leaders into agents of change.

The definition of transformational leadership style in nursing is the nursing leader who motivates his followers (nurses) to work towards goals for the good of the organization. The bass theory states that transformational leadership is a leadership behavior that can activate the motivation of followers and encourage them to act on these motivations for good and high performance. Where are the characteristics of transformational leadership; (1) Ideal influence: giving vision and sense of mission, instilling pride, respect and trust; (2) Inspirational motivation: communicating high expectations, using symbols to focus effort, expressing important goals in a simple way; (3) Intellectual stimulation: promoting intelligence, rationality and careful problem solving; and (4) Individual considerations: give personal attention, treat each employee individually, coach and advice (Robbins and Judge, 2015).

\section{Motivation}

Robbins and Judge (2015) define motivation as a process that takes into account the intensity, direction, and strength of a person towards achieving goals. Motivation in nursing is to give encouragement, strength, enthusiasm to the nurse to do nursing or a process that takes into account the intensity, direction, and strength of the nurse towards the achievement of nursing goals. The purpose of motivation is to improve morale and job satisfaction, increase work productivity, maintain stability, improve discipline, streamline discipline, create a good atmosphere and work relationship, increase the level of welfare, enhance the sense of responsibility for their duties and improve the efficiency of the use of tools and raw materials (Husibuan, 2005 in Asmuji, 2012).

Mc Clelland's theory of motivation is; (1) The need for achievement or Need For Achievement (nAch) is the drive for achievement, to achieve relationships with a set of standards; (2) The need for power or Need for Power (nPow) is the need to make other people behave in ways that they should not do; and (3) The need for affiliation or Need for Affiliation (nAff) is the desire for a friendly and close interpersonal relationship (Robbins and Judge, 2015). This study uses Mc Clelland's theory to increase the motivation of nurses, so that nurses are motivated and have a positive impact on the satisfaction and performance of nurses so that nursing services become better. There are three needs that increase motivation that must be applied in nursing, namely the need for achievement, the need for power and the need to be affiliated.

\section{Job Satisfaction}

Kreitner and Kinicki (2008) state that job satisfaction is an affective or emotional response to various aspects of one's work. Job satisfaction in nursing is the emotional state of the nurse who is pleasant or unpleasant looking at his work. In nursing, the factors of job satisfaction must be increased, because if the job satisfaction of nurses increases it will 


\section{International Advanced Research Journal in Science, Engineering and Technology}

Vol. 7, Issue 12, December 2020

\section{DOI 10.17148/IARJSET.2020.71214}

improve nursing. Several factors of job satisfaction. Job satisfaction factors are; (i) relationship factors, for example the relationship between a manager and a subordinate; (ii) physical factors and working conditions, social relations, suggestions from working friends; (iii) individual factors such as people's attitudes to work, age of people in employment, gender; (iv) factors of family circumstances; and (v) recreational factors, including education (Harold in Sunyoto, 2012). Robbins and Judge (2015) stated that there are five factors of job satisfaction, namely; (1) The work itself, someone prefers work that gives them the opportunity to use their skills and abilities and offer a variety of tasks, freedom and feedback; (2) Job promotion, where someone will feel satisfied if given a promotion at his job; (3) Salaries or wages, someone wants a system of wages and wisdom in promotions that they perceive as fair and in line with their appreciation for work; (4) Awards from superiors, someone will feel satisfied when given an award from their superiors, even if only in the form of praise; and (5) Supporting co-workers, the need for social interactions such as having friendly and supportive co-workers will lead to increased job satisfaction.

\section{Performance}

Hamzah and Lamatenggo (2014) define performance as a person's behavior that produces certain work results after fulfilling a number of requirements. Triwibowo (2013) nurse performance is a form of professional service which is an integral part of health care. In nursing care, performance can be interpreted through the compliance of professional nurses in implementing nursing care according to standards.

Cherie and Gebrekidan (2013) stated that there were five performance assessment objectives, namely; (1) Provide information that underlies personal management decisions such as salary increases, promotions, transfers or dismissals; (2) Assisting in their personal development; (3) Information on performance appraisal will help to assess the effectiveness of recruitment assessment and practice; (4) Provision of information to organizations that will help to identify training and development needs; and (5) Assisting the setting of performance standards is often used as a criterion for assessing the validity of personnel selection and training procedures and Cherie and Gebrekidan (2013) stated that performance appraisal is a systemic review of an individual's individual performance used to evaluate the effectiveness of their work.

Motowidlo and Van (1994) state that there are two types of performance in work, namely; (1) Task performance is the ability in a specific task of the worker, work assignment is defined as an addition to behaviors that provide assistance spontaneously; and (2) Contextual performance is someone volunteering to help a coworker who is left behind, acting in certain ways to maintain a good working relationship or to exert extra effort to complete a task on time. In hospitals the assessment is generally adjusted to the needs of the assessment, to produce an objective assessment, the evaluation of the work of the nurse can be done by various aspects that are adjusted to the level / position of the nurse. Kuntoro (2010) stated that such aspects include work performance, responsibility, obedience, honesty, cooperation, initiative and leadership.

\section{HYPOTHESIS DEVELOPMENT}

A good nurse's performance can be seen from how a nurse is able to show the results of his work in providing nursing services at the hospital. Some of the most important things in improving the performance of nurses in performing nursing are leadership style, motivation, and job satisfaction. As stated by Gibson (2012) that leadership style, motivation, and job satisfaction are able to encourage someone to improve their performance.

\section{H1: Transformational leadership towards job satisfaction}

Metwally et al. (2014) show that transformational leadership has a positive effect on employee job satisfaction at the largest multinational FMCG in the Egyptian context. Research conducted by Malik (2017) shows that the components of transformational leadership affect employee job satisfaction in five Pakistani Islamic banks. Research conducted in Malaysia by Osman (2014) shows that there is a relationship between transformational leadership and satisfaction. Meanwhile, research conducted in health institutions by Ahmad et al. (2013) show that transformational leadership style has more contribution to nurse job satisfaction compared to transactional leadership style in Malaysian health services. Research by Abdelhafiz et al. (2015) showed that there was a positive relationship between job satisfaction and the total score of transformational leadership style and transactional leadership style also had a positive relationship with job satisfaction, however, the overall relationship between job satisfaction and passive-avoidant leadership style was negative in private hospitals in Amman.

\section{H2: Transformational leadership on performance}

Gibson (2012) said the factors that influence performance, one of which is leadership. Performance theory is a multiplication function of ability, leadership and opportunity to perform (safety to participate) with the formula: Performance $=\mathrm{f}$ (Leadership, Ability, opportunity to perform), with the understanding that if one factor is low, then one's performance will be low and vice versa (Blumberg and Pringue in Putri, 2009). 


\section{International Advanced Research Journal in Science, Engineering and Technology}

Vol. 7, Issue 12, December 2020

\section{DOI 10.17148/IARJSET.2020.71214}

The information above shows that factors in improving performance, with good leadership will encourage the spirit of subordinate's work and indirectly improve organizational performance. In leadership there is a leadership style so that the leadership style influences performance.

Gyanchandani Research (2017) shows that there is a relationship between transformational leadership style and employee performance in the IT sector in Pune. Schaubroeck's (2007) research shows that transformational leadership influences team performance through team mediation effects, potential financial services of Hongkong and U.S. multinational banks. Paracha's (2012) research shows that transactional and transformational are both significantly positive related to employee performance but transactional leadership is more significant than transformation. Another important finding was that there was no mediating role in job satisfaction between transactional leadership. But it mediates with the transformation of leadership and employee performance in Pakistani Private Schools (Educators). Meanwhile, research conducted in the health sector by Khan et al. (2016) shows that the nature of transformational leadership has a positive effect on performance but is not significant while the nature of transactional leadership has an important constructive influence on the performance of Karachi, Pakistan hospital employees. Basri et al. (2017) shows that there is a relationship between transformational leadership and the performance of private employees at the Malaisya pharmacy.

\section{H3: Motivation towards job satisfaction}

Suarli and Bahtiar (2012) stated that there are two factors that influence performance and job satisfaction, one of which is motivation. Herzberg's two-factor theory states that dissatisfaction and satisfaction in work appear in two separate dimensions (factor groups). Extrinsic conditions of good work will eliminate dissatisfaction, but not to cause satisfaction. These factors are called hygiene factors. While the intrinsic condition of a good job will bring satisfaction and can be a motivation to work, so it is called a motivational factor.

Suttikun's research (2017) shows that motivation affects employee job satisfaction at Thai SPA. Hope theory helps researchers explain that spa therapists will increase motivation if they believe that their hard work will produce the desired results. If the desired results are fulfilled, the motivation cycle continues and job satisfaction increases. Lambrou's (2010) study shows that health care tends to be more motivated by intrinsic factors, which implies that this must be the target of effective employee motivation in the hospital, and this study shows there is a relationship between motivation and job satisfaction. Ferawati (2016) the results of the study indicate that motivation affects the job satisfaction of nurses.

\section{H4: Motivation for performance}

Suarli and Bahtiar (2012) stated that there are two factors that influence performance and job satisfaction, one of which is motivation. Gibson (2012) also stated that the factors that influence performance are motivation.

The Pongpearchan study (2016) shows that there is an influence between motivation and performance of lecturers in the Thai higher education institutions. Grant's (2008) study shows that intrinsic motivation strengthens the relationship between prosocial motivation and performance. While the research conducted in health services by Awosusi (2011) showed that there was an influence of motivation on the performance of nurses, this study showed that nurses in the region were getting paid and motivated so that it affected the performance of nurses. Research conducted by Hee et al. (2016) shows that intrinsic and extrinsic motivation is positively related to nurse performance. Meanwhile, research by Aly et al. (2016) showed that nurses' satisfaction with performance appraisal had a very significant positive impact on the intrinsic motivation of nurses and the work of nurses.

\section{H5: Job satisfaction with performance}

Barakat's research (2015) shows that job satisfaction transmits the effects of cultural intelligence on performance in Brazilian multinational companies. Research conducted by Talasaz et al. (2014) shows that there is a positive relationship between satisfaction and performance of midwives. Khan et al. (2012) show that there is a relationship between job satisfaction and performance. While the research of Syaiin (2007) showed that satisfaction with supervision had a significant influence on the performance of employees at the Medan Bestari Clinic.

Paltis et al. (2015) shows that there is a relationship between job satisfaction and nurse performance. Meanwhile, the research conducted by Asad (2013) shows that there is a relationship between job satisfaction aspects of work, salary, development opportunities, co-workers and supervision with the performance of nurses in the inpatient unit of Hasanuddin university hospitals.

From the description above, the research model can be described as follows: 


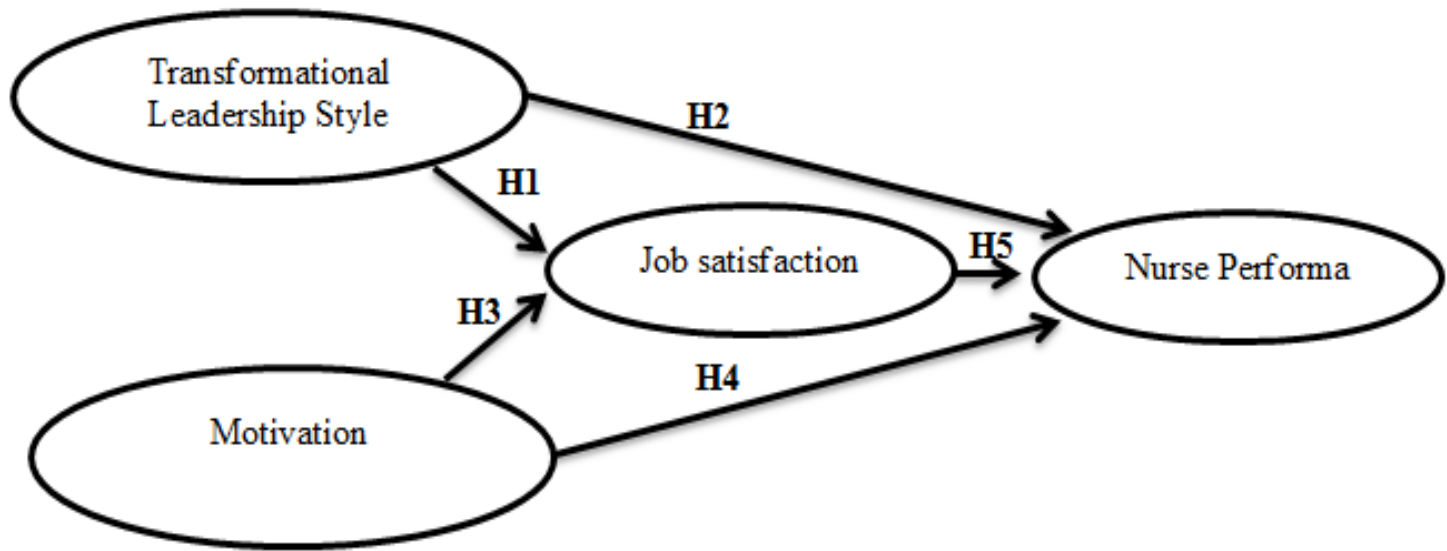

Figure 1

Research model

\section{RESEARCH METHODS}

This research was conducted on all nurses in RSUD dr. H. Marsidi Judono, Belitung Regency. The aspects studied are transformational leadership, motivation, job satisfaction and performance. The study was conducted in March 2018 with the survey method. This research is a descriptive analysis, with a causality model or influence relationship. Data collection was carried out by distributing questionnaires to all nursing staff. Sampling will use saturated samples, the number of samples obtained by 172 respondents. Data analysis method in this study uses SEM statistics, the data is processed using statistical software. The collected data is then measured by measuring the variables in this study using a Likert scale which is adjusted to each tool used. The results of the analysis are then interpreted and the final step is concluded and given advice.

\section{MEASUREMENT (MEASUREMENT)}

Pre test is done by distributing 30 respondents; The results of this study use confirmatory factor analysis, by validity testing by looking at the Kaiser-Meyer-Olkin measure of sampling (KMO) and measures of sampling adequacy (MSA). In this test the value obtained must be greater than 0.5 , which means that factor analysis is appropriate or appropriate for use, and can be further processed (Malhotra, 2007).

In getting KMO transformational leadership style the Idealized Influence dimension shows that the Kaiser Meyer-Olkin Measure of Sampling Adequacy value is 0.769, while the Inspirational Motivation dimension is 0.749, Intellectual stimulation is 0.745 and Individual Consideration is 0.765 which means there is a significant correlation between dimensions and the indicator considering this number is above the value of 0.50. While KMO motivation shows that the Kaiser Meyer-Olkin Measure of Sampling Adequacy value needs of achievement is 0.796, while the dimension of power needs is 0.729 and the need for affiliation or friendship dimensions is 0.821 , which means there is a significant correlation between indicators considering this number already above the value of 0.50 . Furthermore KMO job satisfaction is 0.808 and $\mathrm{KMO}$ performance is 0.838 so it is significant because it is above the value of 0.50 .

Then reliability test, reliability test with Alpha Cronbach value> 0.6 which means reliable. Alpha Cronbach's transformational leadership style with Idealized Influence dimension is 0.886 , while Inspirational Motivation dimension is 0.813 , Intellectual stimulation is 0.856 and Individual Consideration is 0.806, which means that all dimensions are greater than or equal to 0.6 then reable. Whereas Alpha Cronbach motivation with the dimensions of the need for achievement is 0.873 , while the dimension of the need for power is 0.769 and the dimension of need for affiliation or friendship is 0.885 , which means that all dimensions are greater than or equal to 0.6 then declared reable. Furthermore Cronbach Alpha job satisfaction of 0.913 and Cronbach Alpha performance of 0.938 is greater than 0.6 , then it is stated as reable.

\section{RESULTS AND DISCUSSION}

According to Fornell and Larcker (1981) the requirements for good reliability are having construct reliability>0.6 and variance extracted $>0.5$. Construct reliability Transformational leadership style is 0.96 , motivation is 0.93 , job satisfaction is 0.88 and performance is 0.92 , all variables have met the requirements. While variance extracted transformational leadership style is 0.88 , motivation is 0.83 , job satisfaction is 0.52 and performance is 0.54 , all variables have met the requirements.

Based on the structure of the equation model shows the $\mathrm{R}^{2}$ value of each equation. The $\mathrm{R}^{2}$ value serves to show how far the independent variable is able to explain the dependent variable. R2 value for each equation. $\mathrm{R} 2$ value serves to show how far the independent variable is able to explain the dependent variable. The results that can be analyzed are the 


\section{International Advanced Research Journal in Science, Engineering and Technology}

Vol. 7, Issue 12, December 2020

\section{DOI 10.17148/IARJSET.2020.71214}

influence of transformational leadership style and motivation towards job satisfaction together can be explained $78 \%$, while the remaining $22 \%$ is explained by other variables not included in this study. The results that can be analyzed are the influence of transformational leadership style, motivation and job satisfaction on performance together can be explained $87 \%$, while the remaining $13 \%$ is explained by other variables not included in this study.

Structural model evaluated Chi Square value 3 is stated as good fit because Chi Square $<5$, RMSEA $=0.11$ is poor fit, because RMSEA> 0.10. ECVI models (8.05) compared with ECVI saturated models (5.44) and ECVI Independent models (167.29). AIC model (1376,52) compared with AIC saturated $(930,00)$ and AIC independence $(28605,82)$. The CAIC model (1778.82) is far from the CAIC saturated (2858.58) and also further from the CAIC independence (28730.24), the smaller value shows a good match. Normed fit index (NFI) 0.95 (above 0.90) indicates good fit. CFI 0.97 (above 0.90) indicates Good fit. Tucker-Lewis Index or Non Normed Fit Index (NNFI) 0.96 (above 0.90) indicates Good fit. Incremental Fit Index (IFI) 0.97 (above 0.90) indicates Good fit. Relative Fit Index (RFI) = 0.95 (above 0.90 ) indicates Good fit. Parsimonius Normed Fit Index (PNFI) 0.81 (above 0.6) is used for model comparison, indicating sufficient compatibility. Standardized RMR $=0.33$ (above 0.05) indicates poor fit. Goodness of Fit Index (GFI) $=0.68$ (below 0.90) indicates poor fit and Adjusted Goodness of Fit Index (AGFI) $=0.60$ (below 0.90) indicates poor fit. Parsimony Goodness of Fit Index $(\mathrm{PGFI})=0.54$, it shows a good model, because PGFI values range from 0 to 1 , showing a good model.

In this study, there are five hypotheses tested and based on the test results, it is concluded that the four hypotheses are supported by data. Following are the results of testing the overall hypothesis:

Table 1

Testing Hypothesis Results

\begin{tabular}{|c|l|c|c|}
\hline Hypothesis & Hypothesis statement & $\begin{array}{l}\text { T-Value } \\
\text { Value }\end{array}$ & Information \\
\hline H 1 & $\begin{array}{l}\text { The influence of transformational } \\
\text { leadership style on job satisfaction }\end{array}$ & 2,06 & $\begin{array}{c}\text { There are } \\
\text { Influences }\end{array}$ \\
\hline H2 & $\begin{array}{l}\text { The influence of Transformational } \\
\text { leadership style on performance }\end{array}$ & 2,32 & $\begin{array}{c}\text { There are } \\
\text { Influences }\end{array}$ \\
\hline H3 & $\begin{array}{l}\text { The influence of motivation on job } \\
\text { satisfaction }\end{array}$ & $\begin{array}{c}\text { There are } \\
\text { Influences }\end{array}$ \\
\hline H4 & $\begin{array}{l}\text { The influence of motivation on } \\
\text { performance }\end{array}$ & 3,04 & $\begin{array}{c}\text { There are } \\
\text { Influences }\end{array}$ \\
\hline H5 & $\begin{array}{l}\text { The influence of job satisfaction on } \\
\text { performance }\end{array}$ & 0,68 & $\begin{array}{c}\text { There is no } \\
\text { influence }\end{array}$ \\
\hline
\end{tabular}

\section{DISCUSSION}

\section{H1 The Influence of Transformational Leadership Style on Job Satisfaction}

$\mathrm{X}$ and Y leadership theory, this theory regarding behavior management towards subordinates (how to treat it) which is related to employee satisfaction (Nursalam, 2014). Transformational leadership is a leadership behavior that can activate the motivation of followers and encourage them to act on these motivations for good and high performance (Robbins and Judge, 2015). While a person's motivation will arise what if they get satisfaction in work (Gibson, 2012). In the first test results (H1), it was found that the results of the analysis support the H1 hypothesis, namely there is an influence between transformational leadership style of 2.06 on job satisfaction. This shows that job satisfaction is influenced by the transformational leadership style of the nursing unit of Dr. H. Marsidi Judono Belitung Regency. The higher the transformational leadership style will further improve the satisfaction of the performance of nurses in RSUD dr. H. Marsidi Judono Belitung Regency.

These results indicate a positive influence between transformational leadership style and job satisfaction, meaning that the higher the level of transformational leadership style, the higher the level of job satisfaction. This is consistent with research from Malik (2017) showing that the components of transformational leadership have an effect on employee job satisfaction in five Pakistani Islamic banks. A series of previous research conducted in Malaysia by Osman (2014) also shows that there is a relationship between transformational leadership and satisfaction. 


\section{International Advanced Research Journal in Science, Engineering and Technology}

Vol. 7, Issue 12, December 2020

\section{DOI 10.17148/IARJSET.2020.71214}

\section{H2 The Influence of Transformational Leadership Style on Performance}

Bass theory states that transformational leadership influences one's performance. Where are the characteristics of transformational leadership; (1) Ideal influence: giving vision and sense of mission, instilling pride, respect and trust; (2) Inspirational motivation: communicating high expectations, using symbols to focus effort, expressing important goals in a simple way; (3) Intellectual stimulation: promoting intelligence, rationality and careful problem solving; and (4) Individual considerations: give personal attention, treat each individual employee, coach, suggestion. (Robbins and Judge, 2015). Gibson (2012) also stated that one of the factors that influence leadership is performance.

The second test results (H2), found that the results of the analysis support $\mathrm{H} 2$ hypothesis, namely there is no effect between transformational leadership style of 2.32 on performance. This shows that the performance is influenced by the transformational leadership style of the hospital. Marsidi Judono Belitung Regency.

The results of the study were carried out at dr. H Hospital. Marsidi Judono Belitung Regency. that transformational leadership style does not affect the ups and downs of the performance of nurses in dr. H. Marsidi Judono, Belitung Regency, on average nurses think that the ideal influence, inspirational motivation, intellectual stimulation and individual considerations of the head of the nursing head have not been able to influence the performance of nurses.

This result is in accordance with previous research conducted in the field of health by Khan et al. (2016) shows that the nature of transformational leadership has a positive effect on performance but is not significant while the nature of transactional leadership has an important constructive influence on the performance of Karachi, Pakistan hospital employees. Basri et al. (2017) shows that there is a link between transpormational leadership and the performance of private employees in Malaysian pharmacies.

\section{H3 The Influence of Motivation on Job Satisfaction}

There are two factors that influence performance and job satisfaction, one of which is motivation (Suarli and Bahtiar, 2012). Gibson (2012) also states that a person who obtains satisfaction in work will cause motivation in him to act to achieve high work performance. Motivation is the intensity of a person's desire to start or continue to be involved in pursuing a goal (Phillips and Gully, 2014). Mc Clelland's theory states that there are three motivational factors that influence a person's satisfaction, namely the need for achievement, the need for power and the need to be affiliated (Robbins and Judge, 2015).

In the first test results (H3), it was found that the results of the analysis supported the $\mathrm{H} 3$ hypothesis, namely there was an influence between motivation of 2.12 on job satisfaction. This shows that job satisfaction is influenced by motivation. The higher the motivation, the greater the satisfaction of the performance of nurses in $\mathrm{dr}$. $\mathrm{H}$. Marsidi Judono Belitung Regency.

Suttikun's research (2017) shows that motivation affects employee job satisfaction at Thai SPA. Hope theory helps researchers explain that spa therapists will increase motivation if they believe that their hard work will produce the desired results. If the desired results are fulfilled, the motivation cycle continues and job satisfaction increases. Previous research conducted by Suttikun further supports the results of this study.

\section{H4 The Influence of Motivation on Performance}

Factors that influence performance are ability factors and motivation factors, human performance $=$ ability + motivation (Robbin, 2002 in Nursalam, 2014). The fourth test result (H4), found that the results of the analysis did not support the $\mathrm{H} 4$ hypothesis, which is that there is a motivation effect of 3.04 on performance. This shows that performance is influenced by motivation. The higher the motivation, the more performance of nurses in Dr.H. Marsidi Judono Belitung Regency.

Previous research strengthens the results of this study, research conducted by Pongpearchan (2016) shows that there is an influence between motivation and performance of lecturers in Thai government higher education. While Grant's (2008) research also shows that intrinsic motivation strengthens the relationship between prosocial motivation and performance.

\section{H5 The Influence of Job Satisfaction on Performance}

Robbins and judge (2015) state the impact of job satisfaction on employee performance. Employees who feel satisfied with their work are more likely to talk about positive things about their organization, help others and do their job performance beyond normal estimates. There are five factors of job satisfaction that affect a person's job satisfaction, namely the relationship between employees, the work factor itself, the promotion factor, the salary or wage factor and the reward factor from the employer.

The fifth test result (H5), found that the results of the analysis did not support the H5 hypothesis, ie there was no motivation effect of 0.68 on performance. This shows that performance is influenced by job satisfaction. The higher job satisfaction will further improve the performance of nurses in dr. H Hospital. Marsidi Judono Belitung Regency. Research conducted by Aini et al. (2014) also Yogyakarta shows job satisfaction does not affect the performance of 


\section{International Advanced Research Journal in Science, Engineering and Technology}

Vol. 7, Issue 12, December 2020

\section{DOI 10.17148/IARJSET.2020.71214}

nurses, and research conducted by Abidin (2010) shows job satisfaction does not have a significant effect on performance.

This result is not in accordance with the research of Khan et al. (2012) show that there is a relationship between job satisfaction and performance. Meanwhile, research by Paltis et al. (2015) shows that there is a relationship between job satisfaction and nurse performance.

Nurse job satisfaction does not affect the ups and downs of nurses' performance in dr. H. Marsidi Judono Belitung Regency. Dr.H. Hospital Marsidi Judono, Belitung Regency is a type $\mathrm{C}$ hospital, type $\mathrm{C}$ and type A hospitals are very different, where type $\mathrm{C}$ hospitals with not too many patients and a conducive work environment, the interaction between nurses and superiors is quite good. Nurses feel the communication and cooperation of nurses goes well in their work units, as they help each other in dealing with difficult patients, the workload they feel is not too heavy.

The work that nurses do regularly and continuously does not make a nurse feel difficult because the nurse is required to do all the work well. The results of previous interviews dropped and increased job satisfaction occurred when a nurse experienced rolling a room with another friend, because new things would happen, both habits, environment, superiors, friends working the room, and they had to be able to adjust quickly. These conditions can be a decrease in job satisfaction in some time, and a decrease in the performance of nurses, but these conditions do not last long because these conditions will be a motivation to be able to adjust to the new room, new equipment, new room chief and new roommate, so that their performance improvement cannot be determined by job satisfaction alone.

\section{MANAGERIAL IMPLICATIONS}

Managerial implications in transformational leadership style based on dimensions, dimensions of inspiration motivation held leadership training with core competency material, dimensions of intellectual stimulation held leadership training with Job competency material, ideal influence dimension held leadership training with leadership competency material and individual consideration dimensions held communication training, coaching and mentoring. While managerial implications in motivating according to dimensions, the dimensions of the need for prestige give an additional incentive of 3 days to outstanding nurses, the dimension of power gives the incentive for promotion or career allowances and the dimension of need for friendship affiliates gives an incentive in the form of family gathering activities.

Managerial implications of job satisfaction carry out questionnaire dissemination surveys and managerial performance implications carry out communication training and nursing care training for all nurses in dr. H. Marsidi Judono Belitung Regency.

\section{CONCLUSION}

It was concluded that the increasing transformational leadership style also increased job satisfaction and the performance of nurses in dr. H. Marsidi Judono Belitung Regency. Dr.H. Hospital Marsidi Judono Regency. Whereas the increasing motivation of the nurses $t$ then also increased the job satisfaction and performance of nurses in $\mathrm{dr}$. $\mathrm{H}$ Hospital. Marsidi Judono Belitung Regency. But not the case with job satisfaction on performance, increasing and decreasing performance is not affected by job satisfaction.

From the explanation above, it can be concluded that the purpose of the research is that only four objectives are fulfilled, because the influence of each variable is illustrated from the results of the analysis of the data obtained from the distribution of questionnaires in the sample studied. The results of the study explain that transformational leadership style influences job satisfaction and nurse performance. Motivation affects job satisfaction and nurse performance, but job satisfaction does not affect the performance of nurses at the dr. H. Marsidi Judono Belitung Regency. So that in improving performance must pay attention to leadership style, motivation and job satisfaction, because of the increase in leadership style, job satisfaction and motivation will improve the performance of nurses at dr. H. Marsidi Judono Belitung Regency. The increasing performance of nurses will create a quality hospital, where nurses are the most human resource component in the hospital and perform services in direct contact with patients.

\section{RESEARCH LIMITATIONS}

Limitations of research that can be a consideration for further research. This study has a limited number of samples that still need improvement in the days of the day even though the samples that have been taken are saturated samples from all nurses studied. This study uses a questionnaire as a measurement tool because of the need to save time and energy. This questionnaire also has limitations such as answers that are still biased in filling out questionnaire questions, there is a possibility that respondents do not fill in the actual situation or just fill in based on the expected ideal conditions and not the actual conditions that are happening, because the process of filling out the questionnaire was not conducted by interview directly but only through mentoring when filling out the questionnaire. Then it can cause the measurement used is not able to describe the variables significantly.

Limitations in the number of samples and variables that influence transformational leadership style, motivation, job satisfaction and performance. So the number of analyzes caused researchers not to be able to dig deeper into other factors that influence transformational leadership style, motivation, job satisfaction and nurse performance. 


\section{International Advanced Research Journal in Science, Engineering and Technology}

Vol. 7, Issue 12, December 2020

\section{DOI 10.17148/IARJSET.2020.71214}

\section{SUGGESTIONS FOR FURTHER RESEARCH}

This research is still very limited because it only conducts research in one hospital so the sample is limited, it is expected to conduct research in several hospitals so that the sample is sufficient. It is hoped that research uses other research methods such as FGDs, so that they get better results in data collection.

\section{REFERENCES}

[1]. Abdelhafiz. 2015. Impact of Leadership Styles Among Head Nurses on Level of Job Satisfaction among staff. European Scientific Journal. University of Tabuk.

[2]. Abidin, Nur.2010. Pengaruh Kepuasan, Motivasi dan Kedisiplinan Kerja terhadap Kinerja Pegawai di Lingkungan Kantor Wilayah Depar temen Agama Provinsi JawaTengah. Program Pasca Sarjana Universitas Dian Nuswantoro Semarang.

[3]. Ahmad, Abd Rahman etal. 2013. The Influence Of Leadership Style on Job Satisfaction among Nurses. Faculty of Technology Management and Business, University Tun Hussein Onn Malaysia.

[4]. Aini et al.2014. Pengaruh Gaya Kepemimpinan dan Kepuasan Kerja terhadap Kinerja Perawat diruangan Rawat Inap A RSUP DR, Soeradji Tirtonegoro Klaten. Pasca sarjana Manajemen Rumah sakit: Universitas Muhammadia Yogyakarta.

[5]. Aly, Nagah Adb El-Fattah Mohamed dan El-Shanawany, Safaa Moustafa. 2016. The Influence Of Performance Appraisal Satisfaction on Nurses' Motivation and Their Work Ourcomes In Critical Care And Toxicology Units. Eropean Scientific Journal. Faculty of Nursing, Alexandria University.

[6]. As' ad. 2013. Hubungan Kepuasan Kerja Dengan Kinerja Perawat Di Unit Rawat Inap Rumah Sakit Universitas Hasanuddin Tahun 2013. Fakultas Kesehatan Masyarakat: Universitas Hasanuddin Makasar.

[7]. Asmuji. 2012. Manajemen Keperawatan Konsep dan Aplikasi. Yogyakarta: Az-Ruzz Media.

[8]. Awosusi et al. 2011. Motivation and Job Performances Among Nurses In The Ekiti State Environment of Nigaria. International Journal of Pharma and Bio Sciences. Faculty of The Social Sciences.University of Ado-Ekiti.

[9]. Barakat. 2015. "Global managers An analysis of the impact of cultural intelligence on job satisfaction and performance" .International Journal of Emerging Markets vol 10 n0 4.

[10]. Basri, Haslina Hassan et al. 2017. The Roles of Transformational Leadership Style for Maintaining Employee In Team Performance; Empirical Study In Malaysia ‘ Pharmacy Industry. International Journal of Buiness and Management vol.9, no. 2.

[11]. Cherie, Amsale dan Gebrekidan, Ato Berhane. 2013. Kepemimpinan dan Manajemen Keperawatan. Yogyakarta: Imperium.

[12]. Ferawati. 2016. Pengaruh Imbalan dan Motivasi Terhadap Kepuasan Kerja Perawat Badan Layanan Umum (Blu) pada Rumah Sakit Bhayangkara Makassar. Jurnal Mirai Management.

[13]. Fornell, C and Larcker D.F.1981. Evaluating Structural Equation models with unobseruable variables and measurement error. Journal of marketing. Research.18 (1) 39-50.

[14]. Gibson, James L et al. 2012. Organizations: Behavior, Structure, Processes. America: Library of Congress Cataloging.

[15]. Grant, Adam M. 2008. Does Intrinsic Motivation Fuel the Prosocial Fire? Motivational Synergy in Predicting Persistence, Performance, and Productivity. Journal of Applied Psychological Association vol. 93, no. 1, 48-58.

[16]. Gyanchandani, Rajni. 2017. The Effect of Transformasional Leadership Style on Team Performational in IT Sector. The IUP Journal of Soft Skills vol. 6, no. 3.

[17]. Hamzah, Uno dan Lamatenggo, N. 2014. Teori Kinerja dan Pengukurannya. Cetakan kedua. Jakarta: Bumi Aksara.

[18]. Hee, Ong Choon dan Kamaludin, Noor Hayati Binti. 2016. Motivation and Job Performance Among Nurses In The Private Hospital Malaysia. International Journal of Caring Sciences. Universiti Teknologi Malaysia.

[19]. Huber, Diane L. 2017. Leadership and Nursing Care Management, 6th Edition. Phyladelphia: Saunders Elsevier.

[20]. Ivancevich, John M. et al. 2007. Perilakudan Manajemen Organisasi. Jakarta: Erlangga.

[21]. Kemenkes RI. 2016. Info Datin PusatData dan Informasi Kementrian Kesehatan RI.

[22]. Khan, Alamdar Hussain etal. 2012. Impact Of Job Satisfaction on Employee Performance: An Empirical Study Of Autonomous Medical Institutions Of Pakistan. Journal of Business Management.

[23]. Khan, Reza et al. 2016. Effects of Leadership Style on Health Care Organizational Performance: A Survey of Selected Tertiary care hospital in karachi, Pakistan. International Journal of Economics \& Management Sciences. Institute of Business and Technology (IBT)

[24]. Kreitner, Robert \& Kinicki, Angelo. 2008. Organizational Behavior. New York: McGraw-Hill Inc.

[25]. Kuntoro, Agus. 2010. Buku Ajar Manajemen Keperawatan. Yogyakarta: Nuha Medika.

[26]. Lambrou, Persefoni etal. 2010. Motivation and Job Satisfaction Among Medical and Nursing Staff in A Cyprus Public General Hospital. Faculty of The Social Sciences: Hellenic Open University.

[27]. Malik, Umer Waqas. 2017. Influence of Transformational Leadership Components on Job Satisfaction and Organizational Commitment. University of Gujrat, Pakistan. Journal of Commerce and Sciences vol. 11 (1) 146-165.

[28]. Malhotra. 2007. Marketing Research An AppliedOrientation. International Edition: Pearson.

[29]. Metwally. 2014. The impact of transformational leadership style on employee satisfaction.

[30]. Nursalam. 2014. Manajemen Keperawatan Aplikasi dalam Praktik Keperawatan Profesional Edisi 4. Jakarta: Salemba Medika.

[31]. Osman, Zolkifli Bin. 2014. The Affective Commitment As Amediator In Relationship Between Military Commanders Transformational end Transactional Leadership with Subordina Tes Job Satisfaction In Malaysian Royal Signals Corp. University of Malaysia. Journal of Defence and Security vol.5, no. 1, 44-61.

[32]. Paltis et al. 2015. Relation Between Job Satisfaction An Job Performance In Healthcare Services. Technological Educational Institute of Central Greece.

[33]. Paracha. 2012. Impact of Leadership Style (Transformational \& Transactional Leadership) On Employee Performance \& Mediating Role of Job Satisfaction. Study of Private School (Educator)In Pakistan. International journal publisher: Globaljournal Inc (USA) vol 12 issue 4 ISSN $2249-4588$.

[34]. Pongpearchan, Purit. 2016. Effect of Transformational Leadership and High Performance Work System on Job Motivation an Task Performance: Empirical Evidence from Business Schools of Thailand Universities. Journal of Business and Retail Management Research vol. 10 Issue 3.

[35]. Putri, Wijayanti Sumarjo. 2009. Kajian Peningkatan Kinerja Pegawai pada PT. Permata Medialand. Magister Manajemen: Universitas EsaUnggul.

[36]. Russel.C. dan Richard.J. 1999. Introductory Management and Leadership for Nurses. Second Edition. Canada : Jones and Bartlett Publisher.

[37]. Robbins, Stephen P \& Judge, Timothy A. 2015. Organizational Behavior. America: Global Edition.

[38]. Talasaz, Zahra Hadizadeh et al. 2014. The Relationship Between Job Satisfaction and Job Performance Among Midwives Working In Healthcare Centers Of Mashhad, Iran. Journal of Midwifery \& Reproductive Health. Mashhad University of Medical Sciences, Mashhad, Iran. 


\section{International Advanced Research Journal in Science, Engineering and Technology}

Vol. 7, Issue 12, December 2020

\section{DOI 10.17148/IARJSET.2020.71214}

[39]. Triwibowo, Cecep. 2013. Manajemen Pelayanan Keperawatan di Rumah sakit. Jakarta: CV. Trans Info Media.

[40]. Schaubroeck, John et al. 2007. Embracing Transformational Leadership: Team Values and the Implact of Leader Behavior on Team Performance. Journal of Applied Psychologi vol. 92, no. 4, 1020-1030.

[41]. Soleman, Agrivani A., Pelealu, F.J.O dan Maramis, Franckie, R.R. 2017. Hubungan Antara Pelatihan dan Motivasi Kerja Dengan Kinerja Tenaga Keperawatan di Rumah Sakit Ibu dan Anak Kasih Ibu Manado Tahun 2017. Fakultas Kesehatan Masyarakat: Universitas Sam Ratulangi Manado.

[42]. Suarli, S dan Bahtiar, Yanyan. 2012. Manajemen Keperawatan dengan Pendekatan Peraktis. Jakarta: Erlangga.

[43]. Suttikun, Chompoonut, Chang, Hyo Jung dan Bicksler, Hamilton. 2017. A Qualitative Exploration Of Day Span Therapists' Work Motivations and Job Satisfaction. Journal of Hospitality and Tourim Management. Faculty of Business Administration and Accountancy, Khon Kaen University.

[44]. Van Scotter, J. R., Motowidlo, S. J., \& Cross T. C. (1994). Effects of task performance and contextual performance on systemic rewards. Journal of Applied Psychology, 85(4), 526-535. 